\title{
INFLUENCE OF DIFFERENT PLANT GROWTH REGULATORS ON CALLUS INDUCTION AND FLAVONOID CONTENTS IN ALFALFA (Medicago sativa L.).
}

Mohamed, M. K ${ }^{1}$; G. G. Shehab ${ }^{2}$; Abeer A. Mahmoud ${ }^{1}$; Alia A. Amer ${ }^{3}$

1- Botany Department, Plant Physiology Section, Faculty of Agriculture, Cairo University, Giza, Egypt.

2- Biochemistry Department, Faculty of Agriculture, Cairo University, Giza, Egypt.

3- Plant Biotechnology Research Lab, Faculty of Agriculture, Cairo University, Giza, Egypt.

\begin{abstract}
Alfalfa contains many important substances including flavonoids which play many diverse roles in plant. Alfalfa callus was induced on media containing 6- benzyl aminopurin (BA), $\alpha$ - Naphthalene acetic acid (NAA), 2, 4 Dichloro phenoxy acetic acid $(2,4-D)$ and kinetin. The best callus formation was obtained from the medium of 2 $\mathrm{mgl}^{-1} 2,4-\mathrm{D}+1.5 \mathrm{mgl}^{-1}$ Kinetin; leaf was the best organ of alfalfa in production of fresh weight. The $2^{\text {nd }}$ subculture was higher in growth characters and flavonoids production as compared to the $1^{\text {st }}$ subculture. Flavonoid concentration was higher in shoot tip of $1^{\text {st }}$ subculture and leaves in the $2^{\text {nd }}$ subculture.
\end{abstract}

Keyword: Alfalfa, callus, plant growth regulators, flavonoid.

\section{INTRODUCTION}

Alfalfa (Medicago sativa L.) is a leguminous plant species that originated in different places at the world. This plant species has been grown for a variety of purposes such as soil improvement, animal feed, medicinal uses and suitable foliage (Stepppler, 1987). Alfalfa had consisted on major constituents as coumarines, alkaloids, vitamins, porphyrines, stachydrine, homostarchydrine and flavonoids (Duke, 1985; Rogers, 1997). Flavonoids are plant secondary metabolites found in most terrestrial vascular plants. They belong to a group of natural phenolic substances with variable chemical structures and in plants more than 6000 different flavonoids have been identified, many of them are responsible for the attractive colors of flowers, fruits and leaves (Nijveldt et al., 2001). The interesting biological activities of flavonoids have prompted the intensive research on physiological properties of these compounds and their effects on human health. Their wide occurrence, complex diversity and manifold functions have made flavonoids a very attractive system for research on a molecular-biological level. Up to date, vast amount of knowledge on flavonoids has been accumulated. This has provided the tools and the know-how for successful metabolite engineering of the flavonoid pathway (Forkmann and Martens, 2001). Flavonoids possess significant antihepatotoxic, antiallergic (Dicarlo et al., 1999), anti-inflammatory, antiosteoporotic, and antiatherogenic effects (Ishimi et al., 1999), antitumor, 
antiproliferative, and anticancer activities (Kuo, 1996; Birt et al., 2001; Manthey and Guthrie, 2002); as well as antioxidant (Hollman and Katan, 1999; Havsteen, 2002), antiviral (Jassim and Naji, 2003) and inhibition activity against many mammalian enzyme systems in vitro (Middleton et al., 2000).

Thus, in the present experiment there were attempts to cultivate whole plant organs, i.e. shoot tips, roots, leaves and stems under in vitro conditions with the aim to produce medicinally important compound. As it was expected, such organ cultures produced similar patterns of secondary metabolites as intact plants.

\section{MATERIALS AND METHODS}

These experiments were carried out during the period from Aug. 2006 - Dec. 2007 in Plant Biotechnology Research Laboratory, Faculty of Agriculture, Cairo University, Giza, Egypt.

Seeds of alfalfa received from Ornamental Department, Faculty of Agriculture, Cairo University, Giza, Egypt were used in the present experiments

Seeds were germinated on different tissue culture media under aseptic conditions at the rate of 15 seed / jar.

\section{Experiment treatments}

This work included three experiments as follows:

1- Effect of medium types on callus induction.

This experiment consisted of 4 medium types as shown in Table 1.

Table 1: MS medium with different concentrations of growth regulators.

\begin{tabular}{ll}
$A$ & $M S+B A\left(1 \mathrm{mg} \mathrm{l}^{-1}\right)+$ NAA $\left(0.2 \mathrm{mg} \mathrm{l}^{-1}\right)$ \\
$B$ & $M S+B A\left(2 \mathrm{~m} \mathrm{l}^{-1}\right)+\mathrm{NAA}\left(0.2 \mathrm{mg} \mathrm{l}^{-1}\right)$ \\
$C$ & $M S+B A\left(4 \mathrm{~g} \mathrm{l}^{-1}\right)+\mathrm{NAA}\left(0.2 \mathrm{mg} \mathrm{l}^{-1}\right)$ \\
$D$ & $M S+2,4-\mathrm{D}\left(2 \mathrm{mg} \mathrm{l}^{-1}\right)+$ Kinetin $\left(1.5 \mathrm{mg} \mathrm{l}^{-1}\right)$ \\
\hline
\end{tabular}

In vitro procedure

Seeds of alfalfa were surface sterilized by using ethanol (70\%) for 30 sec., then by $20 \%$ commercial bleach (sodium hypochlorite, $0.052 \%$ ) for 20 min followed by 3-4 times washes with sterile distilled water under aseptic condition to release bleach (Ehsanpour and Amini, 2003). The sterilized seeds were cultured on MS basal medium (Murshige and Skoog, 1962), with $3 \%$ sucrose and solidified with $0.7 \%$ agar, $\mathrm{pH}$ was adjusted to 5.7 before autoclaving at $121^{\circ} \mathrm{C}$ for $25 \mathrm{~min}$. Seeds were grown under $16 \mathrm{~h}$ photoperiod at 1250 lux of cool white light and incubated at $24{ }^{\circ} \mathrm{C}$ for $7-10$ days in growth chamber.

Produced seedlings were separated into different types of organs (leaf, stem, root and shoot tip). Each of these explants was cultured in baby jars (150 ml capacity) containing $30 \mathrm{ml}$ of callus induction media shown in 
Table 1. Twenty days after culture, data were taken on the formed callus as following:

1- $\quad$ Callus fresh weight (C. F. W.).

2- $\quad$ Callus diameter (C. D.).

2- Effect of different 2, 4- D concentrations with or without using kinetin of callus induction.

Medium D was showed the best performance regarding callus induction in the first experiment. It was chosen for this experiment. This medium contained $2 \mathrm{mg} \mathrm{l}^{-1} 2$, 4- D and $1.5 \mathrm{mg} \mathrm{l}^{-1}$ Kinetin. Some modifications were made for this medium (Table 2.), and the obtained media were tested on callus induction. All steps regarding callus production were followed as in the first experiment. Moreover, another subculture after 20 days was conducted. Subculture was also done in $150 \mathrm{ml}$ baby jars. Data were taken on produced formed callus of both culture and subculture, as shown in the first experiment.

Table 2: MS medium with different 2, 4- D concentrations with or without using Kinetin.

\begin{tabular}{rl}
\hline T1 & $M S+2,4-D\left(1 \mathrm{mg} \mathrm{l}^{-1}\right)$ \\
T2 & $\left.M S+2,4-\mathrm{D}^{-1} \mathrm{~m} \mathrm{l}^{-1}\right)$ \\
T3 & $M S+2,4-D\left(3 \mathrm{mg} \mathrm{l}^{-1}\right)$ \\
T4 & $M S+2,4-D\left(4 \mathrm{mg} \mathrm{l}^{-1}\right)$ \\
T5 & $M S+2,4-D\left(1 \mathrm{mg} \mathrm{l}^{-1}\right)+$ Kinetin $\left(1.5 \mathrm{mg} \mathrm{l}^{-1}\right)$ \\
T6 & $M S+2,4-D\left(2 \mathrm{mg} \mathrm{l}^{-1}\right)+$ Kinetin $\left(1.5 \mathrm{mg} \mathrm{l}^{-1}\right)$ \\
T7 & $M S+2,4-D\left(3 \mathrm{mg} \mathrm{l}^{-1}\right)+$ Kinetin $\left(1.5 \mathrm{mg} \mathrm{l}^{-1}\right)$ \\
8 & $M S+2,4-D\left(4 \mathrm{mg} \mathrm{l}^{-1}\right)+$ Kinetin $\left(1.5 \mathrm{mg} \mathrm{l}^{-1}\right)$ \\
\hline
\end{tabular}

3- Response of callus flavonoid content to different explants and subcultures.

Different explants, i. e. leaf, stem, root and shoot tip were cultured on medium 6, which consisted of MS + 2, 4- D $\left(2 \mathrm{mg} \mathrm{l}^{-1}\right)+$ kinetin $\left(1.5 \mathrm{mg} \mathrm{l}^{-1}\right)$. Twenty days later subcultures of produced callus were performed as described in experiment 2. Data were recorded on callus produced from explants culture and the subculture as follows:

1- $\quad$ Callus fresh weight (C. F. W.).

2- $\quad$ Callus diameter (C. D.)

3- $\quad$ Flavonoids concentrations ( $\mu \mathrm{g} / \mathrm{g}$ F.W.).

\section{Procedure of flavonoid determination} Sample preparation:

To determine the active constituent flavonoids of the callus produced from different organs in vitro. The different calluses were obtained fresh for analysis. One $\mathrm{g}$ of callus was used for determination of alfalfa flavonoids $(\mu \mathrm{g}$ flavonoids / g F.W), a fresh sample of alfalfa callus was weighted and 
separately mixed with $6 \mathrm{ml}$ of $80 \%$ aqueous methanol by mortar for 2 minute, extracts were obtained under vacuum.

\section{Total flavonoid assay}

Total flavonoid concentration was measured by the aluminum chloride colorimetric assay. An aliquot $(1 \mathrm{ml})$ of extracts or standard solution of quercetin ( $1 \mathrm{ro}^{\circ}, 250,375,500 \mu \mathrm{g} / \mathrm{ml}$ ) was added to $10 \mathrm{ml}$ volumetric flask containing $4 \mathrm{ml}$ of $\mathrm{dd} \mathrm{H}_{2} \mathrm{O}$. To the flask was added $0.3 \mathrm{ml} 5 \% \mathrm{NaNO}_{2}$. After 5 min, $0.3 \mathrm{ml} 10 \% \mathrm{AlCl}_{3}$ was added. At $6^{\text {th }} \mathrm{min}, 2 \mathrm{ml} 1 \mathrm{M} \mathrm{NaOH}$ was added and the total volume was made up to $10 \mathrm{ml}$ with $\mathrm{dd} \mathrm{H}_{2} \mathrm{O}$. The solution was mixed well and the absorbance was measured against prepared reagent blank at $415 \mathrm{~nm}$. (Marinova et al., 2005).

\section{Data analysis}

The experiments were set in three factors completely randomized design (CRD) in and five replicates, each replicate consisted of one jar and each jar contained one explant. The data on different parameters were collected and statistically analyzed. Thereafter, the least significant differences between means of treatments were recorded at $5 \%$ level using L.S.D as described by Steel and Torrie (1960).

\section{RESULTS AND DISCUSSION}

\section{1- Effect of medium types on callus induction.}

In this experiment four different supplementations of growth regulators (2, 4- D, NAA, BA and kinetin) were added to MS medium to obtain the best callus formation (C.F.W and C.D.) from different organs (leaves, stems, roots and shoot tips). Visible callus formation was obtained with in a few days, and data were taken at $20^{\text {th }}$ days of the culture.

a. Effect of medium types on callus fresh weight (C. F. W.).

The obtained results showed that there were significant differences between treatments; the highest C.F.W from all explants was observed on MS supplemented with $2 \mathrm{mg}$ 2, 4- D + $1.5 \mathrm{mg}$ kinetin.

Data indicated that medium A produced alfalfa callus tissue from both roots and leaves and hardly from stems. Only callus tissues were produced from leaves in B and C media. However, the best medium was D which successfully produced callus tissue from all organs of alfalfa plant, where C.F.W obtained from leaf explants on medium $D$ was about of 6.61 times that of medium $A ; 7.43$ times that of medium $B$ and 5.68 times that of medium $C$. Stems and roots gave a higher C.F.W on medium $D$ with 28.33 and 11.82 , times respectively, than that produced on medium A, while they didn't produce callus on other media. Shoot tips produced callus only on medium $D$ (Figure 1.). 


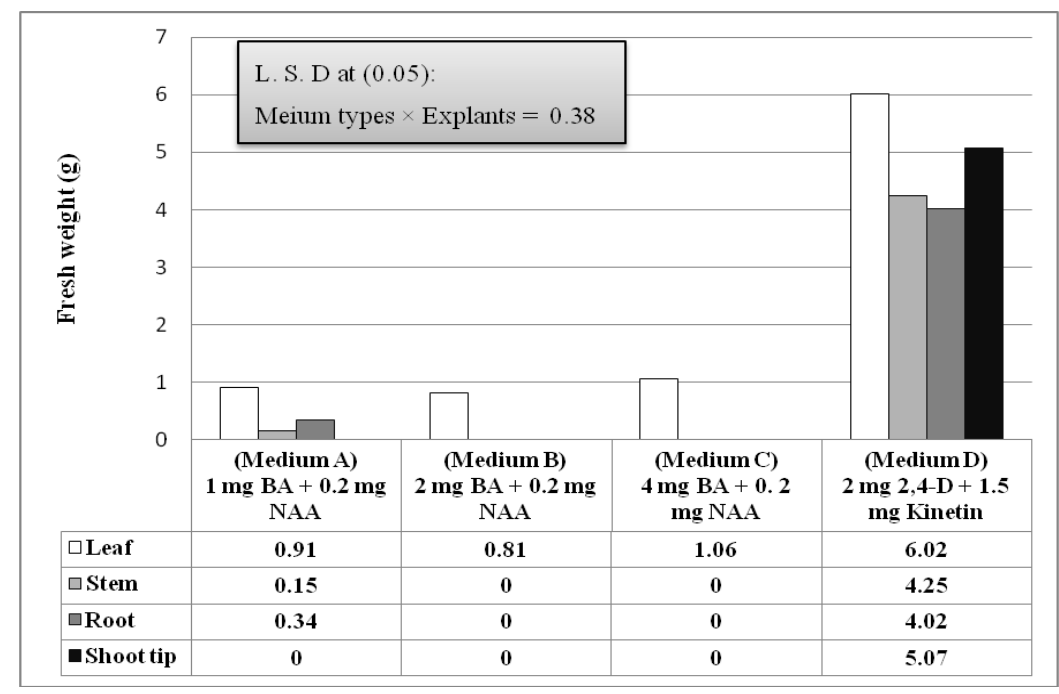

Figure 1: Effect of medium types on callus fresh weight.

b. Effect of medium types on callus diameter (C. D.).

Data indicate that there were significant differences among treatments on C.D. which produced from the different media. The highest callus volume was observed on MS supplemented with $2 \mathrm{mg} \mathrm{l}^{-1} 2$, 4-D + 1.5 $\mathrm{mg} \mathrm{l}^{-1}$ kinetin (Figure 2).

Medium A produced alfalfa callus tissue from both roots and leaves and hardly from stems. Only callus tissues were produced from leaves in B and $C$ media. However, the best medium was $D$ which successfully produced callus tissue from all organs of alfalfa plant. The highest value of callus diameter (C. D.) produced from leaves was obtained on medium $D$ which was about 1.99 times that of medium $A ; 2.78$ times that of medium $B$ and 2.23 times that of medium C. Stems and roots showed a higher C.D. on medium D (11.03 and 2.95 times, respectively than medium A), while they didn't produce any callus on others media. Shoot tips produced callus only on medium D.

Thus, it could be concluded from this experiment that leaf explant was the best part for induction of callus formation and the treatment that contained $2 \mathrm{mg} \mathrm{l}^{-1} 2$, 4- D + $1.5 \mathrm{mg} \mathrm{l}^{-1}$ kinetin was chosen be used in the next experiment. In previous studies on explants of alfalfa callus production, it was stated that 2, $4-\mathrm{D}$ and Kinetin could be necessary for efficient callus formation from all explants, e. g. leaf, stem, root and shoot tip. Similar data were obtained by Ehsanpour and Taheri (2005) who found that alfalfa callus could production on MS medium containing 2, 4- D, Kinetin and NAA. These results are in agreement with Simovic (1985) and Rudus et al. (2002) who noticed that callus of alfalfa was induced from stem explants on MS basal 
medium supplemented with 2, 4- D and Kinetin. In contrast, Zabata et al. (2003) noticed that the combination of 2, 4- D and Kinetin gave no response for callus induction from leaf and root of turmeric (Curcuma longa L.) while the combination of 2, 4- D and BA showed a positive response for callus induction from stem. In our results the best medium for callus formation was 2, 4- $\mathrm{D}$ combined with Kinetin at $2 \mathrm{mg} \mathrm{l}^{-1}$ and $1.5 \mathrm{mg} \mathrm{l}^{-1}$ respectively. The same results were recorded by Moursey et al. (1999). However, in other studies the highest callus induction of alfalfa was obtained in MS medium supplemented with 2, 4- D at $2 \mathrm{mg} \mathrm{l}^{-1}$ and Kinetin $0.5 \mathrm{mg} \mathrm{l}^{-1}$ (Pushpalatha et al., 2005; Kaur et al., 2005; Huiling et al., 2006 and Lanas et al., 2006). Moreover, Mofidabadi et al. (2001) noticed that $2 \mathrm{mg} \mathrm{l}^{-1}$ 2, 4- D with $0.5 \mathrm{mg} \mathrm{l}^{-1}$ Kinetin produced high percentage of callus induction of Populus euphratica oliv. and increasing of 2, 4- D from $2 \mathrm{mg} \mathrm{l}^{-1} 2,4-\mathrm{D}$ to $3 \mathrm{mg} \mathrm{l}^{-1} 2,4-\mathrm{D}$ didn't have any effect on percentage of callus initiation but reducing kinetin concentration from $0.5 \mathrm{mg} \mathrm{l}^{-1}$ to $0.1 \mathrm{mg} \mathrm{l}^{-1}$ with the same amount of 2, 4- D showed great effect on callus induction. On the other hand, Rui Yun et al. (2004) achieved callus induction from turmeric with $1 \mathrm{mg} \mathrm{l}^{-1} 2$ 2, 4- D and 16 $\mathrm{mg} \mathrm{l}^{-1}$ Kinetin. Amoo and Ayisire (2005) noticed that the fact of callus was induced by 2, 4- D but not by NAA suggests that cotyledon explants of $P$. biglobosa are auxin specific. Zafar et al. (1995) also reported that callus induction from cotyledon, hypocotyls and root explants of Medicago littoralis in the presence of 2, 4- D alone and when it was replaced with NAA, these results were in agreement with Jeeva et al. (2005) who noticed that callus induction from leaf of gerbera cultivars on the treatment 2, 4- D $\left(2 \mathrm{mg} \mathrm{l}^{-1}\right)$ with BA (1 $\left.\mathrm{mg} \mathrm{l}^{-1}\right)$ recorded the highest percentage of callus production, while the combination between BA with NAA showed the lowest percentage of callus production.

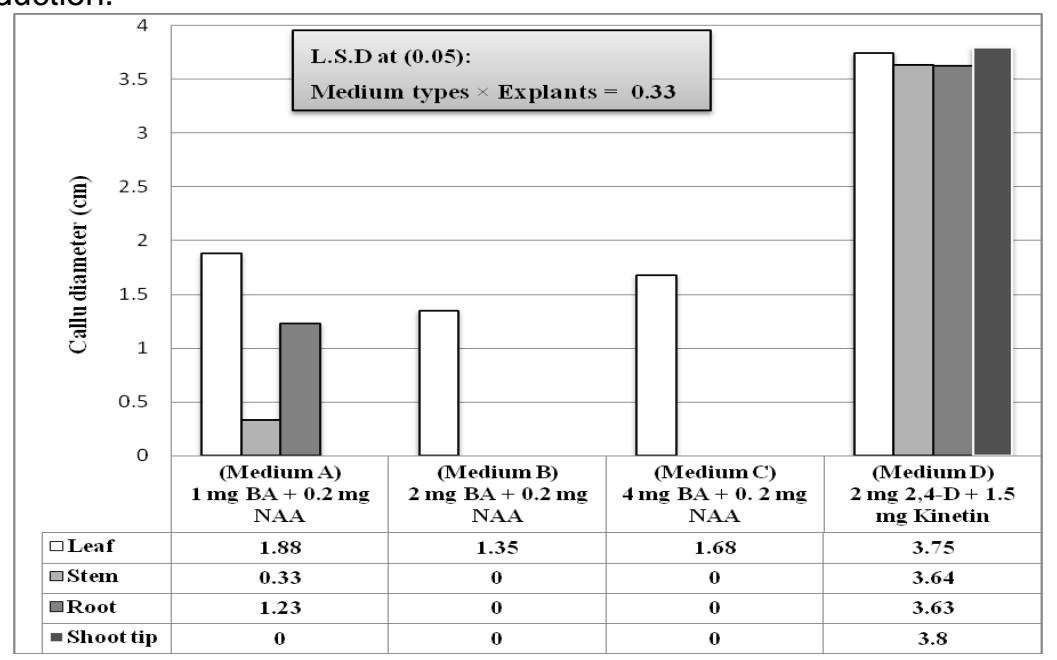

Figure 2: Effect of medium types on callus diameter. 


\section{2- Effect of different 2, 4- D concentrations with or without using kinetin of callus induction.}

The present data showed that leaf was the best explants in producing fresh weight as compared to stem, root and shoot tip of Medicago sativa in vitro callus on both $1^{\text {st }}$ and $2^{\text {nd }}$ subculture. The $2^{\text {nd }}$ subculture produced 3.52 times greater callus fresh weight than the $1^{\text {st }}$ subculture. Thus, the leaf was chosen as the best organ for callus production in the following experiments (Table 3).

As for the media type effects on callus fresh weight, media T6 $(2 \mathrm{mg}$ $\mathrm{I}^{-1} 2$, 4- $\mathrm{D}+1.5 \mathrm{mg} \mathrm{l}^{-1}$ Kinetin) produced the highest mean value of F.W 6.15 $\mathrm{g}$ followed by the media T1 (1 mg 2. 4- D) with the mean value of $3.99 \mathrm{~g} \mathrm{F.W.}$ Hence, the best medium for Medicago sativa callus production was $2 \mathrm{mg} \mathrm{l}^{-1} 2$, 4- $D+1.5 \mathrm{mg} \mathrm{l}^{-1}$ kinetin. Jarszina et al. (2005) observed that the efficiency of callus production for Cannabis sativa L. obtained on MS supplemented with 1 $\mathrm{mg} \mathrm{l}^{-1}$ Kinetin $+0.5 \mathrm{mg} \mathrm{l}^{-1} \mathrm{NAA}, 2 \mathrm{mg} \mathrm{l}^{-1}$ Kinetin $+0.5 \mathrm{mg} \mathrm{l}^{-1} \mathrm{NAA}$ or $2 \mathrm{mg} \mathrm{l}^{-1} 2$, 4- $D$ was highly only for some explants source and cultivars. The highest induction callus was from leaves and petiole. Martin (2004) showed that 2, 4D was the best for the callus formation of Andrographis Paniculata (Burm. F.), while the combination of 2, 4- D and Kinetin was superior. These results are also in agreement with Al- Bahrany and Al- Khayri (2002) who stated that the highest callus induction of "Hassawi" rice occurred on $2.5 \mathrm{mg} \mathrm{l}^{-1} 2$ 2, 4- D alone; however, greatest callus weight was obtained on $1.5 \mathrm{mg} \mathrm{l}^{-1}$ 2, 4- D combined with $2 \mathrm{mg} \mathrm{l}^{-1}$ Kinetin. Kumar and Kanwar $(2006,2007)$ and Kumar et al. (2004) observed that the maximum callus induction and growth in petal explants of Gerbera jamesonii was obtained on MS medium supplemented with 1.5 and $2 \mathrm{mg} \mathrm{l}^{-1} 2$, 4- D in leaf and with $3 \mathrm{mg} \mathrm{l}^{-1} \mathrm{BA}$ in petiole explants. Tam and lang. (2003) found that MS medium with $2 \mathrm{mg} \mathrm{l}^{-1} 2$, 4- $\mathrm{D}$ is conceder as a medium suitable for callus induction of rice cultivars. Jain et al. (2005) reported that $4 \mathrm{mg} \mathrm{l}^{-1} 2,4-\mathrm{D}$ was found to yield maximum callus induction of hybrid bermudagrass Tifton 85 with $88( \pm 13 \%)$ of the explants responding, followed by $66( \pm 11)$ on $3 \mathrm{mg} \mathrm{l}^{-1} 2,4-\mathrm{D}$. Callusing response was lower by 73,34 , and $39 \%$ on 1,2 and $6 \mathrm{mg} \mathrm{l}^{-1} 2,4-\mathrm{D}$, respectively, as opposed to 4 $\mathrm{mg} \mathrm{I}^{-1}$ 2, 4- D. Ibrahim et al. (2007) observed that MS medium supplemented with $1 \mathrm{mg} \mathrm{l}^{-1} 2,4-\mathrm{D}$ is quite suitable for callus induction from hypocotyl and cotyledon explants of Sunflower. In the contrast, Mohammad et al. (2003) mentioned that cytokinins like Kinetin and BA were used alone at 3 and $4 \mathrm{mg}$ $\mathrm{I}^{-1}$, respectively, good callus was observed on MS Medium containing BA at 4 $\mathrm{mg} \mathrm{l}^{-1}$. On the other hand, Hoque et al. (2007) who works on Water Chestnut (Trapa sp.) showed that no callus was induced in 2, 4- D containing media. 
Mohamed, M. K· et al.

Table 3: Effect of different 2, 4- D concentrations with or without using kinetin of callus induction.

\begin{tabular}{|c|c|c|c|c|c|c|c|c|c|c|}
\hline \multirow{2}{*}{$\begin{array}{c}\text { Subculture } \\
\text { (A) }\end{array}$} & \multirow{2}{*}{$\begin{array}{l}\text { Explants } \\
\text { (B) }\end{array}$} & \multicolumn{8}{|c|}{$\begin{array}{l}\text { Media } \\
\text { ( C ) }\end{array}$} & \multirow[t]{2}{*}{ Mean } \\
\hline & & T1 & T2 & T3 & T4 & T5 & T6 & T7 & T8 & \\
\hline \multirow{4}{*}{$1^{\text {st }}$} & Leaves & 2.90 & 2.35 & 3.19 & 0.84 & 0.82 & 3.06 & 0.50 & 0.41 & 1.76 \\
\hline & Stems & 1.22 & 0.90 & 1.07 & 0.35 & 1.23 & 2.84 & 0.22 & 0.26 & 1.01 \\
\hline & Roots & 0.66 & 0.61 & 0.39 & 0.24 & 0.84 & 3.73 & 1.04 & 0.49 & 1.00 \\
\hline & Shoot tips & 2.22 & 1.19 & 1.04 & 0.69 & 1.07 & 1.94 & 0.61 & 0.37 & 1.14 \\
\hline Mean & & 1.75 & 1.26 & 1.42 & 0.53 & 0.99 & 2.89 & 0.59 & 0.38 & 1.23 \\
\hline \multirow{4}{*}{$2^{\text {nd }}$} & Leaves & 6.73 & 6.23 & 6.28 & 2.60 & 5.16 & 10.74 & 2.61 & 2.43 & 5.35 \\
\hline & Stems & 3.97 & 2.05 & 3.76 & 1.33 & 8.32 & 9.76 & 1.08 & 2.65 & 4.12 \\
\hline & Roots & 5.55 & 1.67 & 1.47 & 0.55 & 5.23 & 8.96 & 1.24 & 4.46 & 3.64 \\
\hline & Shoot tips & 8.69 & 2.60 & 1.80 & 0.62 & 5.05 & 8.13 & 3.86 & 2.80 & 4.19 \\
\hline Mean & & 6.23 & 3.14 & 3.33 & 1.28 & 5.94 & 9.40 & 2.20 & 3.08 & 4.33 \\
\hline \multirow{4}{*}{$\begin{array}{c}\text { General } \\
\text { mean } \\
\text { of explants }\end{array}$} & Leaves & 4.82 & 4.29 & 4.74 & 1.72 & 2.99 & 6.90 & 1.56 & 1.42 & 3.55 \\
\hline & Stems & 2.60 & 1.47 & 2.42 & 0.84 & 4.77 & 6.30 & 0.65 & 1.46 & 2.56 \\
\hline & Roots & 3.11 & 1.14 & 0.93 & 0.40 & 3.04 & 6.34 & 1.14 & 2.47 & 2.32 \\
\hline & Shoot tips & 5.46 & 1.90 & 1.42 & 0.66 & 3.06 & 5.04 & 2.23 & 1.58 & 2.67 \\
\hline Mean & & 3.99 & 2.20 & 2.38 & 0.90 & 3.47 & 6.15 & 1.40 & 1.73 & \\
\hline \multirow{7}{*}{$\begin{array}{c}\text { L.S.D at } 0.05 \\
\text { for }\end{array}$} & $A$ & & .13 & & & & & & & \\
\hline & B & & .24 & & & & & & & \\
\hline & C & & .17 & & & & & & & \\
\hline & $5 \times B$ & & .34 & & & & & & & \\
\hline & $\mathrm{B} \times \mathrm{C}$ & & .48 & & & & & & & \\
\hline & $A \times C$ & & .24 & & & & & & & \\
\hline & $\mathrm{A} \times \mathrm{B} \times \mathrm{C}$ & & 67 & & & & & & & \\
\hline
\end{tabular}

3- Response of callus flavonoid content to different explants and subcultures.

a. Effect of subcultures and explant types on fresh weight of alfalfa culture

Data indicate that there were significant differences between explants and subcultures on fresh weight. Figure 3 showed that all explants callus was increased at $2^{\text {nd }}$ sub culture compared with $1^{\text {st }}$ subculture. Leaf fresh weight in the $1^{\text {st }}$ subculture gave the highest value of C.F.W; then shoot tip; following by stem and finally root, while gave the lowest F.W of callus. On the other hand in the $2^{\text {nd }}$ subculture leaf gave the highest weight of callus; then stem following by root and finally shoot tip which gave the lowest weight callus. 
J. Agric. Sci. Mansoura Univ., 33 (6), June, 2008

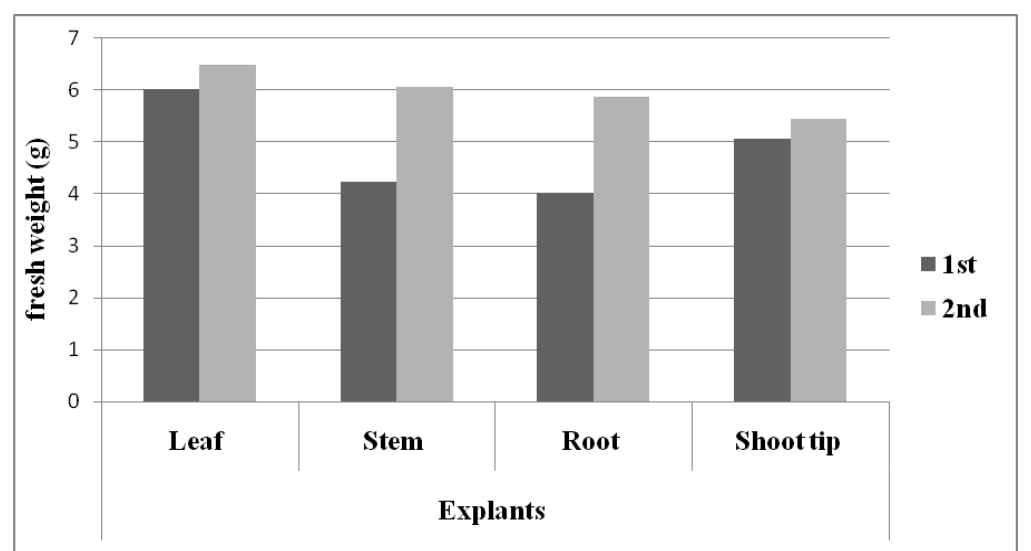

Figure 3: Effect of subcultures and explant types on fresh weight of alfalfa culture.

b- Effect of subcultures and explants type on callus diameter of alfalfa culture.

Data indicate that explants and subcultures had effect on callus diameter. Figure (4) showed that all explants callus diameter was increased at $2^{\text {nd }}$ sub culture compared with $1^{\text {st }}$ subculture. Shoot tip in the $1^{\text {st }}$ subculture exhibited the highest C.D.; followed by root, then stem and finally leaf that gave the lowest C. D. of callus, while in the $2^{\text {nd }}$ subculture leaf gave the highest value of callus; then shoot tip following by stem and root.

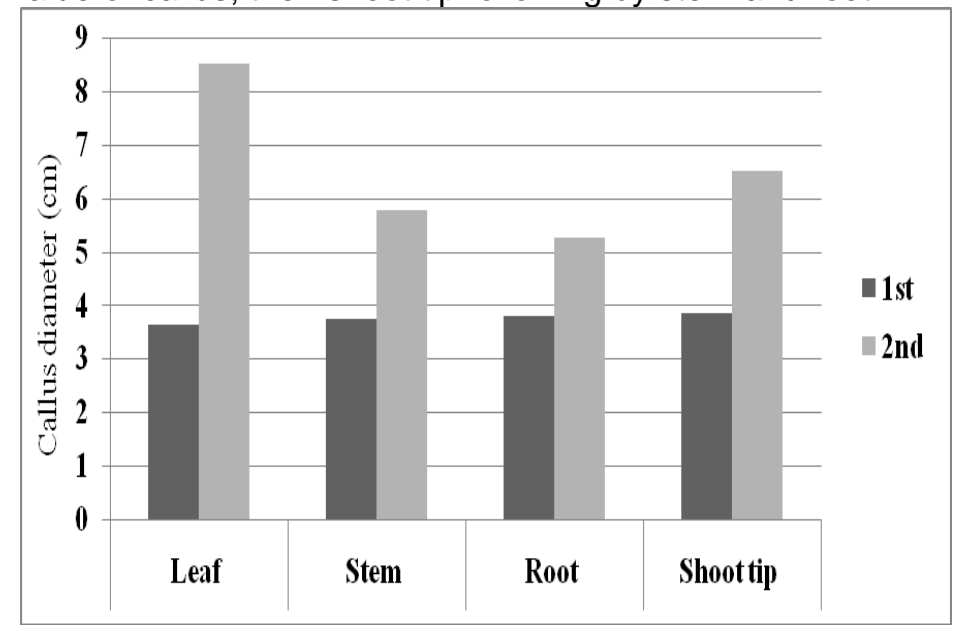

Figure 4: Effect of subcultures and explant types on fresh volume of alfalfa culture. 


\section{c. Effect of subcultures and explants type on total flavonoids concentration of alfalfa culture.}

Explants and subcultures had significant influence on total flavonoids concentration $(\mu \mathrm{g} / \mathrm{g}$. F. W) as shown in Figure 6. Data showed that shoot tip produced the highest level of flavonoid in $1^{\text {st }}$ subculture followed by stem; then root; and at last leaf gave the lowest level of flavonoid concentration. In the $2^{\text {nd }}$ subculture all explants produced less flavonoid than the $1^{\text {st }}$ subculture, except leaf that increased flavonoid in $2^{\text {nd }}$ subculture. In $2^{\text {nd }}$ subculture leaf gave the highest level of flavonoid then shoot tip; followed by root; and stem which showed the lowest level. So, the best explant concerning callus fresh weight, callus diameter and flavonoid concentration was leaf. Similar data were obtained by Cheel et al. (2007) who was working in vitro culture of Sanicula graveolens and found that on dry weight basis, total flavonoid content ranged from $1.23 \%$ to $2.23 \%$ and was lower for the root culture. Chen et al. (2006) found that the callus growth quantity in Cyclocarya paliurus [Pterocarya sp.] was higher in stem than that in the leaf, but the flavonoid content in the leaf was higher than that in the stem and the optimum plant growth regulator combination promoting the callus growth and flavonoid content accumulation was $1.0 \mathrm{mg} \mathrm{l}^{-1}$ kinetin $+0.5 \mathrm{mg} \mathrm{l}^{-1} 2$, $4-\mathrm{D}+0.3 \mathrm{mg} \mathrm{l}^{-1}$ NAA. These results are in agreement with Yamamoto et al. (1986) who mentioned that the growth and flavonoid (baicalin, baicalein, wogonin and wogonin-7-0-glucuronide) content of the St-20 line of Scutellaria baicalensis callus were best on a medium containing 10-7 to 10-5M kinetin. After culture for 70 days the St-20 line had a similar flavonoid content and pattern to that of the parent plant roots. Also, Chen and Cao (2007) observed that flavonoid content in the callus of Ginkgo biloba from different explants was high in root $>$ leaf $>$ cotyledon > stem. On the other hand, Saker and Kawashity (1998), working on Nepeta and Plantago species endemic in Egypt, found that the flavonoid contents of organized tissues, although about 3-times greater than those of unorganized tissues (callus), were still lower than those of the original plants (control). Similar results were found on Lotus tenuis Waldst by Strittmatter et al. (1991) who reported that flavonoids were not detected in vitro callus cultures, but flavonoid production in plantlets derived from the callus showed similar patterns to the field-grown plants. Pasqua et al. (1991) suggested that flavonoid production in Maclura pomifera was markedly higher from cell cultures, although the composition was similar for calluses and cell cultures. Tadhani et al. (2007) showed that the flavonoids content in Stevia rebaudiana was found to be 21.73 and $31.99 \mathrm{mg} / \mathrm{g}$ in the leaf and callus, respectively. Li et al. (2004) working on Eucommia ulmoides plant found that flavonoid contents was highest in hypocotyl calluses. El-Kazzaz and Nazif (2000) working on mulberry plant found that growth regulators IBA and NAA seemed to play an important role in regulating the flavonoid content in callus or in vitro plantlets, with increasing concentrations in the growth medium increasing the flavonoid content. This effect was greater with NAA than with IBA.

In conclusion, the best media for callus weight and volume was $2 \mathrm{mg}$ 2, 4- $\mathrm{D}+1.5 \mathrm{mg}$ Kinetin. Leaf produced the highest callus fresh weight on 
this media. As for effect of 2, 4- D concentration, medium T6 produced the highest callus F.W. and volume in both $1^{\text {st }}$ and $2^{\text {nd }}$ subculture. Leaf was best organ for callus production.

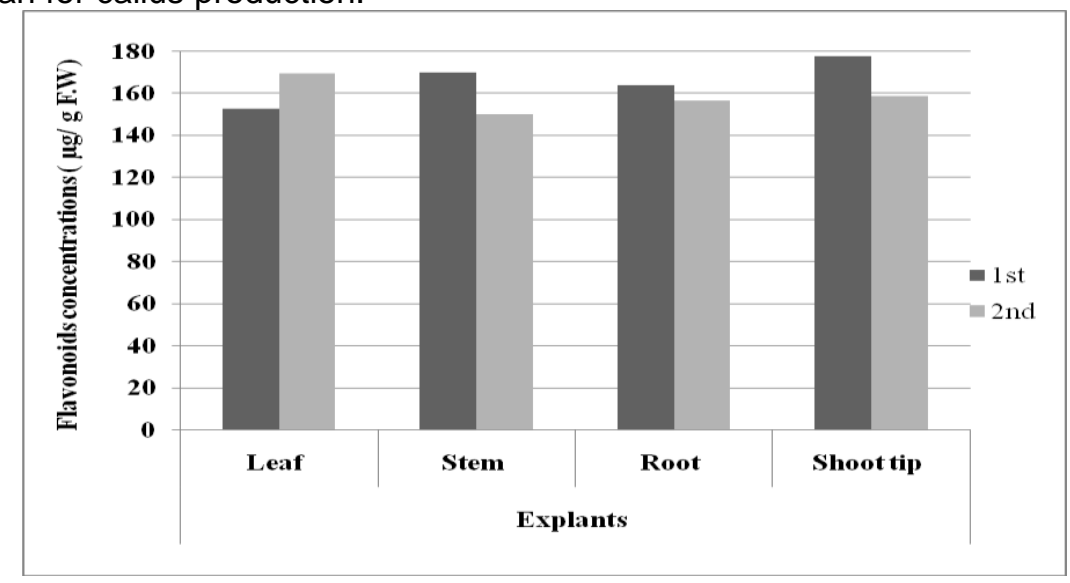

Figure 5: Effect of subcultures and explant types on total flavonoid concentration of alfalfa culture.

\section{REFERENCES}

Al- Bahrany, A. M. and Al- Khayri, J. M. (2002). In vitro plant regeneration of "Hassawi" rice and selection of drought tolerant biotypes through somaclonal variation. Project report, Deanship of Scientific Research, King Faisal Univ., K. S. A . pp. 4.

Amoo, S. O. and Ayisire, B. (2005). Erhinmeyomalnduction of callus and somatic embryogenesis from cotyledon explants of Parkia biglobosa (Jacq.) Benth African Journal of Biotechnology 4 (1): 68-71.

Birt, D. F.; Hendrich, S. and Wang, W. (2001). Dietary agents in cancer prevention: flavonoids and isoflavonoids. Pharmacology and Therapeutics. Therap. 90: 157- 177.

Cheel, J.; Schmeda-Hirschmann, G.; Jordan, M.; Theoduloz, C.; Rodriguez, J. A.; Gerth, A. and Wilken, D. (2007). Free radical scavenging activity and secondary metabolites from in vitro cultures of Sanicula graveolens. Zeitschrift-fur-Naturforschung-Section-C,-Biosciences. 62(7/8): 555-562.

Chen, S. X.; Lan, G. C.; Ying,Y. W.; Jiang, Y. and Gen, S. Y. (2006). Effects of basic media and culture conditions on callus growth and flavonoid content of Cyclocarya paliurus. Journal of Fujian Agriculture and Forestry University. Natural Science Edition. 35(6): 588-592. 
Chen-Ying; Cao-FuLiang. (2007). Leave source from callus induction and flavonoid content in callus from different tissues of five Ginkgo biloba cultivars. Journal of Zhejiang Forestry College. 24 (2): 150-155.

Dicarlo, G.; Mascolo, N.; Izzo, A. A. and Capasso, F. (1999). Flavonoids: old and new aspects of a class of natural therapeutic drugs. Life Sciences. 65: 337-353.

Duke, J. A. (1985). CRC Handbook of medicinal Herbs. CRC Press, Inc., Boca Raton, FL. 677p.

Ehsanpour, A. A and Amini, F., (2003). Effect of salt and drought stress on acid phosphatase activities in alfalfa (Medicago sativa L.) explants under in vitro culture. African Journal of Biotechnology. 2 (5): 133-135.

Ehsanpour, A. A and Taheri, R. (2005). Somatic embryogenesis from alfalfa (Medicago sativa L.)callus using ethinyle estradiol. Journal of Science and Technology of Agriculture and Natural Resources. 9 (1): 103- 11.

El- Kazzaz, A. A. and Nazif, N. M. (2000). Flavonoid content of in vitro micropropagation of mulberry (Morus alba L.). Bulletin of the National Research Centre Cairo. 25(1): 13-22.

Forkmann, G. and Martens, S. (2001). Metabolic engineering and applications of flavonoids. Current Opinion in Biotechnology. 12: 155-160.

Havsteen, B. H. (2002). The biochemistry and medical significance of the flavonoids. Pharmacology and Therapeutics. 96: 67- 202.

Hollman, P. C. and Katan, M. B. (1999). Dietary flavonoides: Intake, Health effects and bioavailability. Food and Chemical Toxicology. 37: 937- 942.

Hoque, A.; Biswas, M. K. and Alam, S. (2006). Variation of callus induction through anther culture in water chestnut (Trapa sp.). Turk J. Biol. 31: 41- 45.

HuiLing, Ma.; XinShi, Lu.; ZhiZhong, Cao. And MiMi, Yu. (2006). Analysis of factors influencing gene transformation in medicago sativa. Acta Prataculturae Sinica. 15 (5): 94- 102.

Ibrahim, L. O.; Nermin, G. and Belma, D. S. (2007). Genotype dependent callus induction and shoot regeneration in sunflower (Helianthus annuus L.). African Journal of Biotechnology 6 (13): 1498- 1502.

Ishimi, Y., Miyaura, G., Ohmura, M., Onoe, Y., Sato, T., Uchiyama, Y., Ito, M., Wang, X., Suda, T. and Ikegami, S. (1999). Selective effects of Genistein, soybean isoflavone, on B-lymphopoiesis and bone loss caused by estrogen deficiency. Endocrinology. 140: 1893-1900.

Jain, M.; Chengalrayan, K.; Meagher, M. G. and Mislevy, P. (2005). Eembryogenic callus induction and regeneration in a pentaploid hybrid Bermudagrass cv. Tifton 85. Crop Sci. 45: 1069- 1072.

Jarzina, A. S.; Ponitka, A. and Kaczmarek, Z. (2005). Influence of cultivar, explants source and plant regulator on callus induction and plant regeneration of Cannabis sativa L. Acta Biologica Cracoviensia 47 (2): 145- 151. 
Jassim, S. A. A and Naji, M. A. (2003). Novel antiviral agents: a medicinal plant perspective. Journal of Applied Microbiology. 95: 412- 427.

Jeeva, L. J.; Balakrishnamoorthy, G.; Kumar, M. V. and Murugesan, R. (2005). Effect of growth regulators on induction of callus in leaf explants of gerbera cultivars. Madras Agric. J. 92 (7- 9): 574- 578.

Kaur, G. P.; Bhardwaj, B. L. and Gosal, S. S. (2005). Induction of somatic embryogenesis and efficient plant regeneration in Trifolium alexandrinum L. Crop Improvement. 32 (1): 1 - 6.

Kuo, S. M. (1996). Antiproliferative potency of structurally distinct dietary flavonoids on human colon cancer cells. Cancer Letters. 110: 41- 48.

Kumar, S.; Kanwar, J. K. and Sharma, D. R. (2004). In vitro regeneration of Gerbera jamesonii Bolus from leaf and petiole explants. J. Plant Biochemistry \& Bioptechnology 13: 73- 75.

Kumar, S. and Kanwar, J. K. (2006). Regeneration ability of petiole, leaf and petal explants in gerbera cut flower cultures in vitro. Folia Horticulturae Ann. 18 (2): 57- 64.

Kumar, S. and Kanwar, J. K. (2007). Plant regeneration from cell suspensions in Gerbera jamesonii Bolus. Journal of Fruit and Ornamental Plant Research. 15: 157- 166.

Lanas, I.; Gallego, P.; Martin, L.; Fernandez, J.; Alonso, A.; Elena-Rosello, J.; Blazquez, A.; Villalobos, N. and Guerra, H. (2006). In vitro culture of Medicago arborea L. anthers: initial response. Plant Growth Regulation. 49(1): 49-60.

Li-Yan; Dong-JuanE; Jiang-ZaiMin and Tang-Rui (2004). Study on dynamic accumulation of secondary metabolites in callus of Eucommia ulmoides. Acta Botanica Boreali Occidentalia Sinica. 24 (11): 20332037.

Manthey, J. A. and Guthrie, N. (2002). Antiproliferative activities of citrus flavonoids against six human cancer cell lines. Journal of Agricultural and Food chemistry. 50, 5837- 5843

Marinova D.; Ribarova F.; Atanassova M. (2005). Total Phenolics and total flavonoids in Bulgarian fruits and vegetables. Journal of the University Chemical Technology and Metallurgy, 40, 3, 2005, 255260.

Martin, K. P. (2004). Plant regeneration protocol of medicinally important Andrographis paniculata (Burm. F.) wallich ex nees via somatic embryogenesis. In Vitro Cell. Dev. Biol. - Plant 40: 204- 209.

Middleton, E.; Kandaswami, C. and Theoharides, T. C. (2000). The Effects of Plant Flavonoids on Mammalian Cells: Implications for Inflammation, Heart Disease, and Cancer. Pharmacological Reviews. 52: 673- 751 . 
Mofidabadi, A. J.; Jorabchi, J.; Shahrzad, S. and Mahmodi, F. (2001). New genotypes development of Populus euphratica oliv. Using gametoclonal variation. Silvae Genetica. 50 (5- 6): 275- 279.

Mohammad, I. S.; Mussarat, J. and Ihsan, I. (2003). In vitro callus induction, its proliferation and regeneration in seed explants of wheat (Triticum aestivum L.) Var.lu-26s. Pak. J. Bot., 35 (2): 209-217.

Moursy, H.A.; Hggag, M.E.A.; Ghanem, S.A. and Rady, M.R. (1999). Callus induction and plant regeneration of alfalfa Medicago sativa $\mathrm{L}$.. Egyptian Journal of Agronomy. 20 (1/2): 179- 189.

Murashige, T. and Skoog, F. (1962). A revised medium for rapid growth and bioassays with tobacco tissue culture. Physiol. Plant. 15: 473-497.

Nijveldt, R.J.; Van Nood, E.; Van Hoorn, D. E. C.; Boelens, P. G.; Van Norren, K. and Van Leeuwen, P. A. M. (2001). Flavonoids: a review of probable mechanisms of action and potential applications. Am J Clin Nutr. 74: 418-425.

Pasqua, G.; Monacelli, B.; Cuteri, A.; Finocchiaro, O.; Botta, B.; Vitali, A.; Monache, G. (1991). cell suspension cultures of Maclura pomifera: optimization of growth and metabolite production. Journal of Plant Physiology. 139 (2): 249-251.

Pushpalatha, A.; Sakhare, S. B.; Sarode, V. P. and Siddanagouda, F. (2005). Callus induction and regeneration studies in pigeonpea. Annals of Plant Physiology. 19 (2): 247- 249.

Rogers, R.D. (1997). Sundew, Moonwort, Medicinal plants of the Prairies. Vol. 1 \& 2. Edmonton, Alberta. 282p.

Rudus, I.; Kepczynska, E. and Kepczynski, J. (2002). Regulation of Medicago sativa L. somatic embryogenesis by gibberellins. Plant Growth Regulation. 36(1): 91- 95.

Rui Yun, W.; Wen Bin, Y. and YouShe, R. (2004). Effects of different Lucerne varieties on induction of calli from leaves and on plant regeneration. Grassland of China. 26 (2): 36- 38, 43.

Saker, M. M. and Kawashity, S. A. (1998). Tissue culture and flavonoid content of Nepeta and Plantago species endemic in Egypt. Fitoterapia.; 69(4): 358-364.

Simovic, N. (1985). Callus induction on alfalfa stem explants (Medicago sativa L.). Glasnik Instituta za Botaniku i Botanicke Baste Univerziteta u Beogradu. 19: 324.

Steel, R. G. D. and Torrie, J.H. (1960). Principles and procedures of Statistics with Special Reference to the Biological sciences. McGraw HillBook Co., Inc., New York 481p.

Steppler, H.A. (1987). ICRAF: A decade of development. In H.A. Steppler and P.K.R. Nair (Eds.) Agroforesty, A decade of development, pp: 13- 24. International Council for Research on Agroforestry, Nairobi, Kenya.

Strittmatter, C. D.; Rivero, M.; Wagner, M.; Kade, M.; Ricco, R. A.; Gurni, A. A. (1991) In vivo and in vitro flavonoid production in Lotus tenuis Waldst. et Kit. Lotus Newsletter. 22: 14-17. 
Tadhani, M.; Patel, V. H.; Rema Subhash. (2007). In vitro antioxidant activities of Stevia rebaudiana leaves and callus. Journal of Food Composition and Analysis. 20 (3/4): 323-329.

Tam, D. M. and Lang, N. T. (2003). In vitro selection for salt tolerance in rice. Omoncice 11: 68- 73.

Yamamoto, H.; Chatani, N.; Kitayama, A. and Tomimori, T. (1986). Flavonoid production in Scutellaria baicalensis callus cultures. Plant-Cell,-Tissueand-Organ-Culture. 1986; 5(3): 219-222.

Zafar, Y.; Nenz, E.; Damlani, F. and Arcioni, S. (1995). Plant regeneration from explants and protoplast derived calluses of Medicago littoralis. Plant cell, tissue and organ culture. 41:41- 48.

Zapata, E.V.; Morales, G.S.; Lauzardo, A.N.H.; Bonfil, B.M. and Tapia, G. T. (2003). In vitro regeneration and acclimination of plants of Turmeric (Curcuma longa L.) in a hydroponic system. Biotechnologia aplicada. 20 (1): $20-31$.

$$
\begin{aligned}
& \text { تأثير منظمات النمو التباتية المختلفة على انتاج الكالس والفلافونويد من }
\end{aligned}
$$

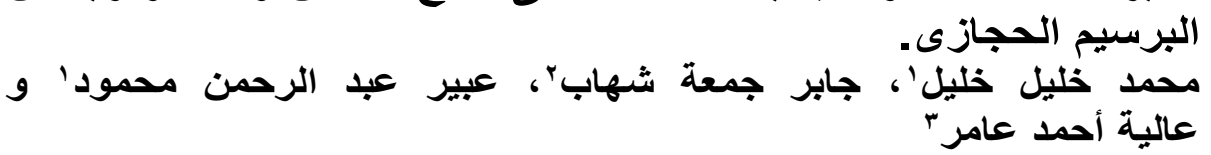

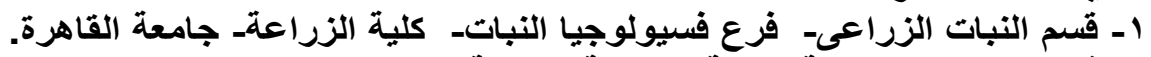

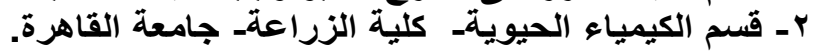

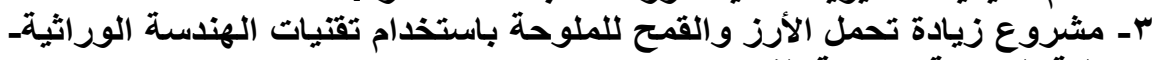

$$
\begin{aligned}
& \text { كلية الزراعة- جامعة القاهرة. }
\end{aligned}
$$

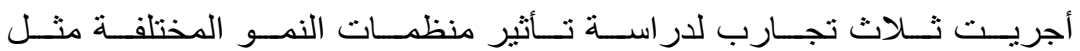

$$
\begin{aligned}
& \text { BA,NAA,2,4-D, Kinetin }
\end{aligned}
$$

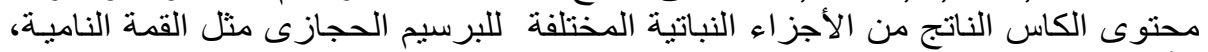

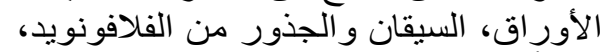

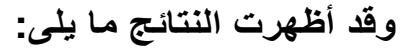

